\title{
Dilutineuron, a new moss genus of the subfamily Racomitrioideae (Grimmiaceae, Bryophyta)
}

\author{
Halina Bednarek-Ochyra, Jakub Sawicki, \\ Ryszard Ochyra, Monika Szczecińska \& Vítězslav Plášek
}

\begin{abstract}
Dilutineuron, a new moss genus of the subfamily Racomitrioideae (Grimmiaceae, Bryophyta). - Acta Mus. Siles. Sci. Natur., 64: 163-168, 2015.

Abstract: Based on available molecular and morphological evidence, the genus Codriophorus P.Beauv. (Grimmiaceae subfam. Racomitrioideae) proved to be a polyphyletic taxon. It consists of two distinct genera which correspond to two sections of Codriophorus, namely sect. Codriophorus and sect. Fascicularia (Bednarek-Ochyra) Bednarek-Ochyra \& Ochyra. The latter section is raised to generic rank as Dilutineuron Bednarek-Ochyra, Sawicki, Ochyra, Szczecińska \& Plášek. The new genus consists of the following five species: D. fasciculare (Hedw.) Bednarek-Ochyra, Sawicki, Ochyra, Szczecińska \& Plášek, comb. nov., D. brevisetum (Lindb.) Bednarek-Ochyra, Sawicki, Ochyra, Szczecińska \& Plášek, comb. nov., D. anomodontoides (Cardot) Bednarek-Ochyra, Sawicki, Ochyra, Szczecińska \& Plášek, comb. nov., D. corrugatum (Bednarek-Ochyra) Bednarek-Ochyra, Sawicki, Ochyra, Szczecińska \& Plášek, comb. nov. and D. laevigatum (Mitt.) Bednarek-Ochyra, Sawicki, Ochyra, Szczecińska \& Plášek, comb. nov.
\end{abstract}

Keywords: Bryophyta, Bucklandiella, Codriophorus, Frisvollia, Niphotrichum, nomenclature, Racomitrium, taxonomy

\section{Introduction}

In the traditional circumscription (e.g. Bruch, Schimper \& Gümbel 1845; Schimper 1860; Brotherus 1924; Loeske 1913, 1930), Racomitrium Brid. was a typical polythetic taxon that could not be defined on the basis of any single character, but it was given cohesion by a specific combination of characters. The most important of these were the leaf areolation of the thick and strongly sinuose to nodulose longitudinal cell walls, the consistent lack of the stem central strand, the usual presence of the prostome, the sinuose-walled epidermal cells of the vaginula, the cladocarpous position of sexual organs, and the special peristome type which, in its typical form, has linear teeth arising from a low or high basal membrane and is divided nearly to the base into two filiform, somewhat paired segments that are equally thickened and less prominently trabeculate on both dorsal and ventral sides. Therefore, some bryologists (Loeske 1930; Frisvoll 1983) argued that Racomitrium was a heterogeneous and unnatural genus which should be split into several distinct genera, well-defined by sets of sporophyte and gametophyte characters.

The infrageneric classification of Racomitrium was quite poorly developed. Kindberg (1898) divided the genus into four unranked groups, namely Lanuginosa, Papillosa, Canescentia and Laevifolia, which were subsequently validated as sections (Noguchi 1974). Bednarek-Ochyra (1995) presented a detailed infrageneric classification of Racomitrium which was largely based on the peristome structure, the shape of the perichaetial leaves and the ornamentation of the laminal cells. The genus was divided into four subgenera, namely subg. Racomitrium, subg. Cataractarum Vilh., subg. Niphotrichum Bednarek-Ochyra \& Ochyra and subg. Ellipticodryptodon (Vilh.) Bednarek-Ochyra \& Ochyra, which corresponded well to the four aforementioned groups recognised within this genus by Kindberg (1898).

A subsequent revisionary study of Racomitrium confirmed that the genus, in its traditional circumscription, was an artificial heterogenerous taxon and, as a result, it was split 
into four genera, Racomitrium s. str., Codriophorus P.Beauv., Niphotrichum BednarekOchyra \& Ochyra and Bucklandiella Roiv. (Ochyra, Żarnowiec \& Bednarek-Ochyra 2003). They are considered to be distinctive taxa through various combinations of unique or otherwise presumably advanced characteristics for the Grimmiaceae, such as the presence of pellucid alar cells, variously papillose laminal cells, papillosity of both seta and calyptra, torsion of the seta, shape of the peristome teeth, anatomy of the costa, and shape of the hair-point.

The molecular phylogeny of the broadly understood genus Racomitrium based on nuclear ITS and plastid rps4-trnL and trnK/matK-psbA sequences, carried out by Larraín et al. (2013), revealed that Bucklandiella and Codriophorus remained polyphyletic, Niphotrichum was paraphyletic and only Racomitrium s. str. could be considered monophyletic. On the other hand, phylogenomic analysis based on complete mitochondrial genomes (Sawicki et al. 2015) fully supported splitting the traditionally conceived genus Racomitrium into four separate genera. In addition, the genus Codriophorus was resolve as paraphyletic mainly due to the phylogenetic position of one species, C. varius (Mitt.) Bednarek-Ochyra \& Ochyra, which is sister to the genus Niphotrichum and forms a common clade with the representatives of this genus. A set of morphological characters, as well as large number of specific mutations in each of analysed genomes, justified the placement of this species in a separate monotypic genus Frisvollia Sawicki, Szczecińska, Bednarek-Ochyra \& Ochyra, with F. varia (Mitt.) Sawicki, Szczecińska, Bednarek-Ochyra \& Ochyra as a sole species.

Subsequent molecular studies on Codriophorus based on complete platomes and mitogenomes as well as nuclear rRNA genes cluster revealed the polyphyletic nature of this genus and provided strong background for futher spliting. The results of these studies will be presented in a separate account which is under preparation by the authors and in the present article taxonomic and nomenclatural conclusions are summarised. They confirm the results obtained by Larraín et al. (2013) based on analysis of nuclear ITS and plastid rps4-trnL and trnK/matK-psbA sequences.

\section{Morphological characterisation of the segregates of Codriophorus}

Codriophorus is primarily diagnosed by a peculiar ornamentation of the laminal cells. They are distinctly papillose, with large flat papillae distributed on both abaxial and adaxial laminal surfaces, and over both the longitudinal walls and most of the lumina, leaving only a narrow slit in the centre. In this character Codriophorus is similar to Racomitrium s. str. but it differs in having the apical portion of the calyptra densely papillose, epilose innermost perichaetial leaves and an entirely smooth, dextrorse seta (exceptionally with one to several twists to the right immediately below the capsule and further down being twisted to the left).

In her monograph, Bednarek-Ochyra (2006) divided Codriophorus into two sections, namely the type section and sect. Fascicularia (Bednarek-Ochyra) Bednarek-Ochyra \& Ochyra. The first of these was lectotypified by C. acicularis (Hedw.) P.Beauv (BednarekOchyra, Lamy \& Ochyra 2001) and it was characterised by several character states, although generally species of this section are markedly differentiated morphologically and this gave the basis to recognition of no fewer than four subsections within it. Species of sect. Codriophorus are generally characterised by simple to irregularly dichotomously branched stems, always without short lateral tuft-like branchlets. The leaves exhibit a broad range of variation, from lingulate to broadly ovate or ovate-lanceolate and they are concave to broadly canaliculate-concave. The leaf margins are variously recurved on one or both sides in the lower half (rarely to three quarters). The section is further characterised by the multistratosity and strong dorsal convexity of the costa in the median and lower parts which, additionally, has a strongly developed stereid band on the dorsal side in the lower part and a single row of enlarged ventral guide cells. The costa is situated at the bottom of a shallow and wide- 
angled groove and it is generally very broad, 85-200 $\mu \mathrm{m}$ wide at the base. The laminal cells are mostly isodiametric in the distal portion and the setae are dextrorse.

The states of stem branching, recurvature of leaf margins, leaf shape and seta torsion are more or less restricted to the type section, but are not shared by all species. For example, Codriophorus dichelymoides (Herzog) Bednarek-Ochyra \& Ochyra, the only species of subsect. Andicola (Bednarek-Ochyra) Bednarek-Ochyra \& Ochyra, has the seta twisted to the right but with only a single torsion to the left immediately below the capsule.

In contrast, Codriophorus sect. Fascicularia is primarily characterised by its peculiar costa. It is pale and concolorous with and usually not sharply set off from the laminal cells. It is situated at the bottom of a deep furrow that is mostly narrow-angled and partly enclosed by the plicate leaf base, less often wide-angled and open and it extends to mid-leaf or vanishes just below or in the leaf apex. In general, the costa is narrow, less than $80 \mu \mathrm{m}$ wide at the base. In transverse section it is bistratose, except for the extreme base where it is in part tristratose or, rarely, it is entirely 3-4-layered. Both ventral and dorsal costal layers are composed of uniform cells and only in the proximal portion or only near the extreme base does the dorsal layer consist of small and thick-walled stereid cells. In addition, the costa varies from slightly prominent on the dorsal surface to nearly of the same thickness as the lamina. It is flat or convex on the ventral side and not prominently convex and crescent-shaped or flattened on the dorsal side.

Some species of Codriophorus sect. Fascicularia, especially C. fasciculare and C. laevigatus, often exhibit a characteristic bunched manner of branching owing to the presence of many short, tuft-like, horizontal, lateral branchlets giving the plants a nodose appearance. Branching of this type is unknown in sect. Codriophorus. Additionally, in all species of sect. Fascicularia (except for $C$. brevisetum) the leaf areolation is composed of elongate cells throughout the lamina, and the stem leaves are straight, lanceolate to ovate-lanceolate, gradually tapering to a short or long, canaliculate acumen. The seta is dextrorse but with a single torsion to the left immediately below the capsule, occasionally with six twists to the left in C. laevigatus.

The strict differences in morphological characters between sect. Codriophorus and sect. Fascicularia are well supported by molecular data. Accordingly, the genus Codriophorus is here split into two genera, Codriophorus s. str. and Dilutineuron warranted by gametophyte and sporophyte character states.

\section{Nomenclatural conclusions}

The aforementioned discussion on morphological and molecular differences exhibited by species of the genus Codriophorus results in the following nomenclatural changes.

Dilutineuron Bednarek-Ochyra, Sawicki, Ochyra, Szczecińska \& Plášek, gen. nov.

Racomitrium sect. Fascicularia Bednarek-Ochyra, Fragm. Florist. Geobot. Ser. Polon. 2: 130. $1995 \equiv$ Codriophorus P.Beauv. sect. Fascicularia (Bednarek-Ochyra) Bednarek-Ochyra \& Ochyra in Ochyra, Żarnowiec \& Bednarek-Ochyra, Cens. Cat. Polish Mosses: 140. 2003. Type: Dilutineuron fasciculare (Hedw.) Bednarek-Ochyra, Sawicki, Ochyra, Szczecińska \& Plášek (Trichostomum fasciculare Hedw., Spec. Musc. Frond.: 110. 1801).

Plants medium-sized to large and robust, mostly coarse and rigid, loosely caespitose, forming dull, yellow, green, yellowish- or brownish-green, olive-brown to brown tufts; sparsely or freely, irregularly, dichotomously to fasciculately branched, usually with many short, tuft-like, lateral, horizontal branchlets giving the plants a nodose appearance. Leaves straight to curved, sometimes falcate, erect and appressed to loosely erecto-patent when dry, erect-spreading or patent when wet, narrowly lanceolate to linear- or ovate-lanceolate, from an ovate, oblong- or ovate-lanceolate base 
gradually tapering to a long, subulate or filiform, canaliculate-concave, straight, flexuous or sometimes wavy to serpentine acumen, smooth or with some longitudinal plicae, yellowishbrown at the insertion; leaf apex epilose, acute, subacute to narrowly rounded-obtuse, entire or dentate, denticulate-cristate to papillose-crenulate, occasionally terminated with a hyaline to yellowish-hyaline, denticulate to serrate hair-point; margins recurved to revolute on both sides from near the base to the apex, incurved and channelled in the upper part, entire throughout or nearly so, sometimes appearing somewhat crenulate due to large, low papillae in the upper part, unistratose throughout to variously bistratose in 1-2(-3) rows of cells distally; costa single, ending in mid-leaf to subpercurrent, situated at the bottom of a deep, narrow- or wide-angled groove below, in transverse section bistratose throughout, with occasional tristratose patches near the base, flattened or convex on the ventral side, weakly convex, lunate or flattened on the dorsal side, with costal cells of similar size and shape or with a dorsal row composed of stereid cells at the extreme base; laminal cells unistratose throughout, long-rectangular to linear or rarely variously bistratose, short-rectangular to isodiametric in the distal part; basal cells rectangular, with strongly incrassate, nodulose and porose walls, forming an intensely bright yellow or yellowbrown, 1-2(-3)-seriate strip along the leaf insertion; basal marginal cells differentiated into 1 (occasionally bi-seriate) row of hyaline, translucent cells with straight walls, forming a marginal border consisting of 5-25 cells; alar cells quadrate to short-rectangular, becoming much wider than the adjacent basal cells, with smooth to sinuose, incrassate walls, forming distinct, flat or often somewhat inflated and decurrent auricles. Dioicous. Outer perichaetial leaves oblong-lanceolate, rather abruptly narrowed to a long, filiform, mostly recurved acumen, hyaline at the extreme tip, with a weak costa extending to the acumen, concolorous with the laminal cells and areolation similar to that of the vegetative leaves; innermost perichaetial leaves oblong, oblong-lanceolate or oblong-ovate to elliptical, convolute, plicate, rounded-obtuse to shortly apiculate at the apex, with a faint subpercurrent costa, hyaline throughout, with entire or uneven margins. Setae 1-3 per perichaetium, erect, twisted to the left immediately below the urn, with 1-6 torsions, clockwise below, minutely grooved. Capsules exserted, erect, straight, ovoid, obloid to shortly cylindrical, smooth, lustrous, brown; operculum conical-rostrate, with a straight rostrum nearly as long as the urn; peristome teeth lanceolate, with a low basal membrane, brown to yellow- or reddish-brown, densely low or spiculate-papillose throughout, divided nearly to the base into 2(-3) filamentous branches. Spores spherical, brownish, minutely papillose. Calyptra conical-mitrate, 4-5-lobed at the base, scabrous at the apex.

Etymology: The genus is named in reference to a costa which is usually of a pale tint and concolorous and imperceptibly merging with the laminal cells (dilutus means of pale tint, neuron means costa in Greek).

Dilutineuron includes the following five species which correspond to Codriophorus sect. Fascicularia sensu Bednarek-Ochyra (2006) from which C. varius (Mit.) Bednarek-Ochyra \& Ochyra was excluded and placed in a separate monotypic genus, Frisvollia Sawicki, Szczecińska, Bednarek-Ochyra \& Ochyra (Sawicki et al. 2015). It is divided into two sections, sect. Dilutineuron and sect. Chrysea. The former accommodates four species from the Northern Hemisphere centred around D. fasciculare, whereas the latter comprises only a single species, $D$. laevigatum, a south-temperate amphiatlantic species, which is the only species of the genus known exclusively from the Southern Hemisphere. It is worth noting that Larrain et al. (2013) placed Bucklandiella shevockii Bednarek-Ochyra \& Ochyra (as Racomitrium shevockii (Bednarek-Ochyra \& Ochyra) Larraín \& J.Muñoz) in Racomitrium sect. Fascicularia Bednarek-Ochyra. Unfortunately, these authors neither explained the reasons for this placement, nor studied any material of the species concerned. They also failed to consider Bucklandiella 
subsect. Shevockia Bednarek-Ochyra \& Ochyra in which this otherwise distinct species from Yunnan Province in China was placed (Bednarek-Ochyra \& Ochyra 2010). This species was merely mechanically transferred by these authors from Bucklandiella to Racomitrium sect. Fascicularia.

\section{Dilutineuron sect. Dilutineuron}

Dilutineuron fasciculare (Hedw.) Bednarek-Ochyra, Sawicki, Ochyra, Szczecińska \& Plášek, comb. nov. BASIONYM: Trichostomum fasciculare Hedw., Spec. Musc. Frond.: 110. 1801.

Dilutineuron brevisetum (Lindb.) Bednarek-Ochyra, Sawicki, Ochyra, Szczecińska \& Plášek, comb. nov. BASIONYM: Racomitrium brevisetum Lindb., Acta Soc. Sc. Fennica 10: 244: 1872.

Dilutineuron anomodontoides (Cardot) Bednarek-Ochyra, Sawicki, Ochyra, Szczecińska \& Plášek, comb. nov. BASIONYM: Racomitrium anomodontoides Cardot, Bull. Herb. Boissier Sér. 2, 8: 335. 1908.

Dilutineuron corrugatum (Bednarek-Ochyra) Bednarek-Ochyra, Sawicki, Ochyra, Szczecińska \& Plášek, comb. nov. BASIONYM: Codriophorus corrugatus Bednarek-Ochyra, Bryologist 107: 377, f. 1-77. 2004.

Dilutineuron sect. Chrysea (Bednarek-Ochyra) Bednarek-Ochyra, Sawicki, Ochyra, Szczecińska \& Plášek, comb. nov.

BASIONYM: Racomitrium sect. Chrysea Bednarek-Ochyra, Fragm. Florist. Geobot. Ser. Polon. 2: 64. 1995.

Dilutineuron laevigatum (A.Jaeger) Bednarek-Ochyra, Sawicki, Ochyra, Szczecińska \& Plášek, comb. nov. BASIONYM: Racomitrium laevigatum A.Jaeger, Ber. Thät. S. Gall. Naturw. Ges. 1872-1873: 90. 1874.

Acknowledgements: This study gained financial support from the Polish National Centre of Science through grant No. N N303 796940 for the first author and, in part, it was also financed through the statutory fund of the Institute of Botany of the Polish Academy of Sciences. The contribution by V. Plášek is part of a research project of the Institute of Environmental Technologies, reg. no. CZ.1.05/2.1.00/03.0100, Project LO1208 of the National Feasibility Programme I of the Czech Republic. We are also much indebted to Rod D. Seppelt, Hobart, Tasmania, for kindly checking the English.

\section{References}

Bednarek-Ochyra H. (1995): Rodzaj Racomitrium (Musci, Grimmiaceae) w Polsce: taksonomia, ekologia i fitogeografia [The genus Racomitrium (Musci, Grimmiaceae) in Poland: taxonomy, ecology and phytogeography]. - Fragm. Florist. Geobot. Ser. Polonica 2: 3-307 (in Polish with extensive English summary).

- (2006): A taxonomic monograph of the moss genus Codriophorus P. Beauv. (Grimmiaceae). W. Szafer Institute of Botany, Polish Academy of Sciences, Kraków, 276 pp.

Bednarek-Ochyra H., Lamy D. \& Ochyra R. (2001): A note on the moss genus Codriophorus P. Beauv. Cryptogamie, Bryologie 22: 105-111.

Bednarek-Ochyra H. \& Ochyra R. (2010): Bucklandiella shevockii (Bryophyta, Grimmiaceae), an exquisite new species from Yunnan, China. - Polish Bot. J. 55: 499-506.

Brotherus V.F. (1924): Musci (Laubmoose). Unterklasse Bryales. II. Spezieller Teil. - In: Engler A. [ed.]: Die Natürlichen Pflanzenfamilien nebst ihren Gattungen und wichtigeren Arten inbesondere den Nutzpflanzen, 10. Wilhelm Engelmann, Leipzig, pp. 143-478.

Bruch P., Schimper W.P. \& Gümbel W.T. (1845): Racomitrium. - In: Schimper W.P. [ed.]: Bryologia europaea seu genera muscorum europaeorum monographicae illustrata. 3. Sumptibus Librariae E. Schweizerbart, Stuttgartiae, pp. 135-147 + Tab. 266-271 [Fasc. 25-28: 13 pp. + 2 \& 8 (Dryptodon) pls.].

Frisvoll A.A. (1983): A taxonomic revision of the Racomitrium canescens group (Bryophyta, Grimmiales). - Gunneria 41: 1-181.

Kindberg N.C. (1898): European and N. American Bryineae (Mosses). 2. Linköpings Lithografiska Akiebolag, Linköping, [i-iii ] + pp. 153-410.

Larraín J., Quandt D., Stech M. \& Muñoz J. (2013): Lumping or splitting? The case of Racomitrium (Bryophytina: Grimmiaceae). - Taxon 62: 1117-1132. 
Loeske L. (1913): Die Laubmoose Europas. I. Grimmiaceae. Max Lande (Hoffmann \& Campe’s Verlag), Berlin-Schöneberg, xvi + 207 pp.

- (1930): Monographie der europäischen Grimmiaceen. Bibl. Bot. 101: i-ix + pp. 1-236.

Noguchi A. (1974): Musci japonici. X. The genus Racomitrium. - J. Hattori Bot. Lab. 38: 337-369.

Ochyra R., Żarnowiec J. \& Bednarek-Ochyra H. (2003): Census catalogue of the Polish mosses. Polish Academy of Sciences, Institute of Botany, Kraków, 372 pp.

Sawicki J., Szczecińska M., Bednarek-Ochyra H. \& Ochyra R. (2015): Mitochondrial phylogenomics supports segregates of Racomitrium (Bryophyta, Grimmiaceae). - Nova Hedwigia 100: 293-317.

Schimper W.P. (1860): Synopsis muscorum europaeorum praemissa introductione de elementis bryologicis tractante. Sumptibus Librariae E. Schweizerbart, Stuttgart, vi + lix + 733 pp. + 1 map + pls. 1-8.

Authors' addresses: Halina Bednarek-Ochyra \& Ryszard Ochyra, Laboratory of Bryology, Institute of Botany, Polish Academy of Sciences, Lubicz 46, 31-512 Kraków, Poland.

E-mails: bednarek@botany.pl; r.ochyra@botany.pl

Jakub Sawicki \& Monika Szczecińska, Department of Botany and Nature Protection, University Warmia and Mazury, Plac Łódzki 1, 10-728 Olsztyn, Poland.

E-mails: jakub.sawicki@uwm.edu.pl; monika.szczecinska@uwm.edu.pl

Vítězslav Plášek, Dept. of Biology and Ecology, University of Ostrava, Chittussiho 10, CZ-710 00 Ostrava, Czech Republic.

E-mail: vitezslav.plasek@osu.cz 